\title{
First SCREening Of Collagen Quality In LEBANESE ARCHAEOLOGICAL BONES
}

\author{
Rana Baydoun and Ziad EI Morr* \\ Lebanese Atomic Energy Commission - National Council for Scientific Research, \\ Beirut, Lebanon \\ *Corresponding author: Ziad El Morr
}

(Received July 2019 - Accepted September 2019)

\begin{abstract}
Beydoun, R. and EI Morr, Z. 2019. First screening of collagen quality in Lebanese archaeological bones. Lebanese Science Journal. 20(3): 495-502.

Radiocarbon dating is a crucial tool for studying national cultural heritage and reconstructing ancient human history. Uncalcined bones, alongside seeds and charcoal, are one of the most reliable materials to be dated, and more precisely the collagen which constitutes around $30 \%$ by weight of the whole bone. However, this collagen may not be well preserved due to the effect of physical and chemical properties of the burial environment. Radiocarbon dating of low-collagen bones could be costly, time consuming and cause destruction of valuable archaeological samples without getting reliable ages. Many techniques were developed to test the state of collagen in bone samples. In this work, an Elemental Analyzer was used on twenty-one bone samples to determine \% $\mathrm{N}, \mathrm{C} / \mathrm{N}$ ratio and to calculate $\% \mathrm{C}$ excess as indicator parameters of collagen preservation. All samples were collected from four coastal Lebanese archeological sites. Percentage nitrogen in 15 samples was below the threshold value $0.7 \%$ and hence they were not adequate for radiocarbon dating. The ratio $C / N$ in the majority of the samples was higher than 5 indicating extensive diagenetic alteration or contamination by exogenous carbon. The percentages excess carbon were lower than maximum acceptable values 5-10\%. Our results emphasize on the importance of collagen prescreening when dating local bone samples which are in many cases degraded.
\end{abstract}

Keywords: Collagen preservation, percentage nitrogen, diagenetic alterations, exogenous carbon.

\section{INTRODUCTION}

Radiocarbon dating method has been widely used for different applications such as forensic studies, ecology, hydrology, geology and the most important one is 
archeology. Age estimation is a critical issue for the archeologists. The radiocarbon dating is the most used tool that allows the determination of absolute age of ancient organic remains in excavation up to approximately 50000 and in some cases up to 60000 (Taylor and Bar-Yosef, 2014; Taylor, 2018) years. Therefore, it plays an important role in building chronologies, reconstructing the ancient past and studying the national cultural heritage. Bone samples are found commonly in archeological contexts and they are one of the most reliable materials to be dated (D'Elia et al., 2007; Zazzo et al., 2009; Scirè Calibrisotto et al., 2013; Saliège et al., 2013; Wood 2015). However, radiocarbon dating of bone samples encountered many challenges especially that the preservation of their chemical and physical properties is highly influenced by the burial environment and could be altered due to the archeological and geological sediments (Smith et al., 2007; Brock et al., 2010). In the Near East, the collagen in bones is particularly badly preserved (Weiner and Bar-Yosef 1990; Scirè Calibrisotto et al., 2013) even though many exceptions are found (Harfouche et al., 2017; Fischer-Genz et al., 2018).

Bone is composed of $20-30 \%$ by weight of organic phase, mainly collagen, and the rest, 60-70\%, is of mineral phase (hydroxiapatite) consisting of phosphates, carbonates and citrates. Although both parts could be dated and many efforts were exerted to develop techniques for this purpose, the most commonly dated fraction is still the collagen due to the fact that it contains about $95 \%$ of the bone's carbon and hence it reduces the sample size for radiocarbon dating (Zazzo et al., 2009; Brock et al., 2013; Pestle et al., 2015). However, this collagen may not be well preserved due to the diagenetic alterations that lead to its progressive degradation till complete loss. The biological and geological processes after burial, causes the graded breakup of hydrogen bond of amino acids chains, the main constituents of collagen (Lebon et al., 2016). Many studies have shown that the collagen is rarely preserved for thousands of years in tropical environments, deserts and in Mediterranean environments (Storm et al., 2013; Wood et al., 2013). Thus radiocarbon dating of low-collagen bone samples could be costly and time consuming without getting reliable results. In addition, unsuccessful sample preparation could lead to partial or total destruction of valuable archeological samples.

For this purpose, during the last decades, several researches have been carried out investigating the mechanism of bone diagenesis and environmental conditions causing collagen degradation. In general, high $\mathrm{pH}$ soil, high temperature, infiltration of groundwater, arid and tropical zones could deteriorate the collagen (Scirè Calabrisotto et al., 2013). Many attempts have been given to develop methods for the determination of collagen preservation state in bone samples using different techniques. Fourier Transform Infrared Spectroscopy was used for the estimation of percentage nitrogen and collagen in the bone based on the amide/ $\mathrm{PO}_{4}$ ratio (D'Elia Cersoy et al., 2016; Lebon et al., 2016). Raman spectroscopy and Ion Beam Analysis were also applied for pre-screening of archeological bones (Beck et al., 2012; Pestle et al., 2015). The simplest, fastest and inexpensive method is the determination of percentage nitrogen in the whole bone sample prior to treatment and collagen extraction using an Elemental Analyzer. Furthermore, the degree of diagenesis or alteration, and the contamination 
arising from exogenous carbon can be assessed using the $\mathrm{C}$ : $\mathrm{N}$ ratio. The acceptable limit of nitrogen content below which the collagen is not well preserved for dating is 0.7-0.8\% (Brock et al., 2012; Lebon et al., 2016; Dumoulin et al., 2017). This will give a rough idea about dating difficulties. This work is a part of collaboration research project "Revisiting the chronological sequence in Lebanon based on C-14 dating", between LAEC- CNRS and the Laboratoire des Sciences du Climat et de L'Environnement (LSCE-UMR 8212- CEA-CNRS-UVSQ). Screening of twenty-one bone samples, collected from four coastal Lebanese archeological sites, was carried out using Elemental Analyzer. These are the first data acquired in Lebanon. The results of percentage nitrogen, $\mathrm{C} / \mathrm{N}$ ratio and $\% \mathrm{C}$ excess will be presented and discussed.

\section{MATERIALS AND METHODS}

\section{Archeological sites}

Twenty-one bone samples were collected from sites RML 79, ASH 163 (Ashrafieh Hill) and BCHK 11 (Bchara el Khoury intersection) in Beirut and TWS 100 on the coast of Tabarja (Kesrouan). These sites were more or less recently (from 2007 till now) excavated using a careful archaeological approach. All samples are human bones except one (RML-79-1) from RML 79 and two bones (BCHK 11-3 and BCHK 11-4) from BCHK 11 belonging to animals.

RML 79 contains levels from different periods including Roman and Bronze Age. We were interested in the earliest one consisting of a Chalcolithic settlement as this period is poorly dated in Lebanon due to absence of absolute dating. The sample was found on the floor of a stone built dwelling. The bones of ASH 163 all belong to human skeletons found in tombs from the Roman period. It should be noted that human burials are very often found in Ashrafieh hill and so it was important to have a first assessment if such bones could be dated. At BCKH 11 and TWS 100 we targeted the Pre-Pottery Neolithic Levels. These periods are also poorly defined in Lebanon chronologically due to the lack of scientifically excavated archaeological sites. The human bones were collected from burials while the animal bones from BCHKH 11 were found in a pit interpreted as a hearth.

\section{Method}

In general bone samples have two parts of different porosities; the cortical compact part and the trabecular porous part which is more susceptible to alteration, diagenesis and contamination and hence not adequate for radiocarbon dating (Dauphin, 2015). A total of 21 animal and human bone samples were collected from four archeological sites and were subjected to pre-screening prior to treatment and collagen extraction for radiocarbon dating. A piece of the cortical part, around 1-2 cm, was cleaned mechanically using airbrasive system with fine aluminium oxide powder to remove superficial contaminants. Then it was drilled out using spherical burr drill bit. About 10-15 mg of cleaned powder bone were weighed and introduced into tin capsules (Brock et al., 2012). The measurement of percentage nitrogen and percentage carbon 
was carried out at the LSCE-UMR 8212- CEA-CNRS-UVSQ, using automated elemental analyzer Thermo Flash EA 1112 Series. Acetalinide was used as reference for quality control, while empty tin capsules were introduced in the run as blank samples. Percentage of nitrogen was used to determine the preservation status of collagen, while the $\% \mathrm{C}$ excess was determined to predict the degree of contamination. The theoretical percentage of carbon ( $\% \mathrm{C}_{\text {theory}}$ ) was calculated according to equation 1 and the exogenous contamination rate $\left(\% \mathrm{C}_{\text {excess }}\right)$ was deduced as prescribed in equation 2 (Dumoulin et al., 2017)

$$
\begin{gathered}
\% \mathrm{C}_{\text {theory }}=2.7 \mathrm{x} \% \mathrm{~N}+1.4 \\
\% \mathrm{C}_{\text {excess }}=\% \mathrm{C}_{\text {measured }}-\% \mathrm{C}_{\text {theory }}
\end{gathered}
$$

\section{RESULTS AND DISCUSSION}

In general, the nitrogen concentration in the whole bone is a good indicator about the quantity of collagen preserved. The concentration of nitrogen in fresh bone is $4 \%$ while a value of $0.7 \%$ is a threshold of acceptable limit below which the sample should not be destroyed for dating (Hedges and Van Klinken, 1992; Tisnérat-Laborde et al., 2003; Brock et al., 2010). The percentage nitrogen, $\mathrm{C} / \mathrm{N}$ ratio and the $\% \mathrm{C}$ excess of the 21 screened samples are shown in table 1. The nitrogen content in all samples collected from the site BCHK11 was below $0.7 \%$ with a minimum value of $0.05 \%$, showing that the collagen is highly degraded. The sample collected from the site RML 79 did not show good collagen preservation as the percentage nitrogen was $0.06 \%$. The bone samples collected from the site TWS 100, were not adequate for radiocarbon dating as they have nitrogen concentration below the threshold value. The majority of the samples collected from the site ASH 163 showed well preserved collagen with percentage nitrogen higher than $0.7 \%$ in six samples. Two samples had nitrogen concentration of $0.3 \%$ and $0.6 \%$ and hence they were not suitable for $\mathrm{C}-14$ dating. This collagen degradation could be attributed to different effects prevailing in the burial environment specially the site hydrology (Hedges, 2002). The flow of groundwater within the site and the wet environment could enhance the development of fungi and bacteria favoring the microbial attack, one of the main reasons of rapid loss of collagen (Hedges, 2002; Smith et al., 2002; Kendall et al., 2017). In addition, the alkalinity of high calcareous Lebanese soil could cause swelling of protein and acceleration of hydrolysis (Collin et al., 2002; Scirè Calabrisotto et al., 2013). The $\mathrm{C} / \mathrm{N}$ ratio in the whole bone give an idea about the state and quality of preserved or residual collagen. Values higher than 5 indicates extensive degree of diagenesis or contamination by exogenous carbon such as that originating from humic acidsand fulvic acids (TisnératLaborde et al., 2003; Brock et al., 2010). Some studies have shown that even a ratio of 17 in the whole bone gives the possibility to extract more than $1 \%$ weight collagen from the bone, however larger quantity of sample will be required (Lebon et al., 2016). 
Table 1. Percentage nitrogen, $\mathrm{C} / \mathrm{N}$ ratio and exogenous contamination rate (\% Cexcess).

\begin{tabular}{|c|c|c|c|}
\hline Sample & \% & $\mathbf{C} / \mathbf{N}$ & \% C excess \\
\hline BCHK11-1 & $0.06 \pm 009$ & $55 \pm 11$ & 1.97 \\
\hline BCHK11-2 & $0.07 \pm 0.01$ & $35 \pm 8$ & 1.05 \\
\hline BCHK11-3 & $0.05 \pm 0.006$ & $65 \pm 12$ & 1.45 \\
\hline BCHK11-4 & $0.15 \pm 0.02$ & $21 \pm 5$ & 1.36 \\
\hline RML 79-1 & $0.06 \pm 0.08$ & $64 \pm 12$ & 2.24 \\
\hline TWS100-1 & $0.02 \pm 0.03$ & $67 \pm 13$ & 0.2 \\
\hline TWS100-2 & $0.11 \pm 0.02$ & $23 \pm 6$ & 0.9 \\
\hline TWS100-3 & $0.06 \pm 0.08$ & $39 \pm 8$ & 0.9 \\
\hline TWS100-4 & $0.04 \pm 0.006$ & $75 \pm 12$ & 1.7 \\
\hline TWS100-5 & $0.09 \pm 0.01$ & $41 \pm 9$ & 1.9 \\
\hline TWS100-6 & $0.03 \pm 0.004$ & $130 \pm 22$ & 2.3 \\
\hline TWS100-7 & $0.09 \pm 0.01$ & $41 \pm 8$ & 2.1 \\
\hline TWS100-8 & $0.14 \pm 0.02$ & $21 \pm 6$ & 1.1 \\
\hline ASH163-1 & $1.46 \pm 0.17$ & $6 \pm 1$ & 8.9 \\
\hline ASH163-2 & $0.29 \pm 0.06$ & $16 \pm 5$ & 2.7 \\
\hline ASH163-3 & $1.38 \pm 0.18$ & $9 \pm 2$ & 11.6 \\
\hline ASH163-4 & $0.79 \pm 0.11$ & $7 \pm 2$ & 5.2 \\
\hline ASH163-5 & $0.92 \pm 0.13$ & $7 \pm 2$ & 5.6 \\
\hline ASH163-6 & $1.56 \pm 0.19$ & $5 \pm 1$ & 7.3 \\
\hline ASH163-7 & $0.58 \pm 0.09$ & $7 \pm 2$ & 1.5 \\
\hline ASH163-8 & $1.58 \pm 0.19$ & $5 \pm 1$ & 7.7 \\
\hline
\end{tabular}

It was found that $\mathrm{C} / \mathrm{N}$ ratio in all samples collected from BCHK11, RML-79 and TWS-100 are higher than 5. Highest values were detected in very poorly-preserved samples or low-collagen samples, such as TWS100-1, TWS100-4 and TWS100-6, this confirm what stated in the literature (Van Klinken, 1999). The $\mathrm{C} / \mathrm{N}$ ratio values could not assert if the samples had undergone diagenetic alterations such as hydrolysis of amino acids or an exogenous carbon had cross-linked to the original organics in the bone samples. For that reason, \% $\mathrm{C}$ excess was determined. Values showed that samples are not highly contaminated as calculated percentages excess carbon were lower than maximum acceptable values 5-10\% (Dumoulin et al., 2017), and hence the high C/N ratio determined in the samples collected from BCHK11, RML-79 and TWS100 could be attributed to extensive diagenesis of the sample due to the physical and chemical factors prevailing in the burial environment, rather than contamination process. Two of eight samples collected from the site $\mathrm{ASH}-163$, have $\mathrm{C} / \mathrm{N}$ ratio equal 5. While five sample were slightly above. Highest ratio was determined in the sample ASH 163-2 of low preserved collagen. The sampleASH163-3 has well preserved collagen, and a C/N ratio slightly higher than 5 . The $\% \mathrm{C}_{\text {excess }} 11.8$ could be attributed to the contamination by humic acids and fulvic acids. Several pretreatment techniques, which are not the subject of this paper, were developed to remove this exogenous carbon. 


\section{CONCLUSION}

Fifteen archeological bone samples out of the screened twenty-one samples had poorly preserved collagen. The $\mathrm{C} / \mathrm{N}$ ratio showed that all samples were subjected to extensive diagenesis or contamination by exogenous carbon. However, the $\% \mathrm{C}_{\text {excess }}$ were lower than maximum acceptable limits confirming the diagenesis process as the main culprit rather than contamination. Further studies regarding the burial environment, such as, but not limited to, composition and $\mathrm{pH}$ of the soil, its porosity, potential infiltration of groundwater or seawater are needed and should be recorded as much as possible during excavations. Development of screening techniques at the LAEC will be carried out to enhance the capabilities to test the state of collagen and avoid destruction of valuable archaeological samples without getting reliable radiocarbon ages.

\section{ACKNOWLEDGEMENT}

The authors express their gratitude to the Laboratoire des Sciences du Climat et de L'Environnement (LSCE-UMR 8212- CEA-CNRS-UVSQ), where the analysis were performed, especially Dr Christine Hatté and Mrs Caroline Gauthier. As well, we thank the scientific directors of the archaeological sites Dr. Assaad Seif, Dr. Georges Abou Diwan and DR Corine Yezbeck for providing archaeological bone samples and relevant information. We extend our gratitude to Mr Hadi Choueiri, the project coordinator.

\section{REFERENCES}

Beck, L. Cuif, J. P. Pichon, L. Vaubaillon, S. Dambricourt Malassé, A. Abel, R. L. 2012. Checking collagen preservation in archologial bone by non-destructive studies (Micro-CT and IBA). Nuclear Instruments and Methods in Physics Research B. 273: 203-207.

Brock, F. Higham T. Bronk Ramsey, C. 2010. Pre-screening techniques for identification of samples suitable for radiocarbon dating of poorly preserved bones. Journal of Archeological Science. 37: 855-865.

Brock, F. Wood, R. Higham, T. F. Ditchfield, P. Bayliss, A. Ramsey, C. B. 2012. Reliability of nitrogen content $(\% \mathrm{~N})$ and carbon: nitrogen atomic ratios $(\mathrm{C}: \mathrm{N})$ as indicators of collagen preservation suitable for radiocarbon dating. Radiocarbon. 54 (3-4): 879-886.

Brock, F. Geoghegan, V. Thomas, B. Jurkschat, K. Higham, T. F. G. 2013. Analysis of bone "collagen" extraction products for radiocarbon dating. Radiocarbon. 55 (23): 445-463.

Cersoy, S. Zazzo, A. Lebon, M. Rofes, J. Zirah, S. 2016. Collagen extraction and stable isotope analysis of small vertebrate bones: A comparison approach. Radiocarbon. 59 (3): 679-694.

Collins, M.J. Nielson-Marsh, C. M. Hiller, J. Smith, C.I. Roberts, J.P. Progodich, R.V. Wess, T. J. Csapò, J. Millard, A. R. Turner-Walker, G. 2002. The survival of organic matter in bone: a review. Archaeometry. 44 (3): 383-394. 
Dauphin, Y. 2015. Os et dents. Pp. 5-21, In: Messages d'os: Archéométrie du squelette animal et humain.

Balasse, M. Brugal, J. P. Dauphin, Y. Geigl, E. M. Oberlin C. Reiche, I. 2018. Edition des archives contemporaines. 531 pp. Paris.

D’Elia, M. Gianfrate, G. Quarta, G. Giotta, L. Giancane, G. Calcagnile, L. 2007. Evaluation of possible contamination sources in the ${ }^{14} \mathrm{C}$ analysis of bone samples by FTIR spectroscopy. Radiocarbon. 49(2): 201-210.

Dumoulin, J. P. Massager, C. Valladas, H. Beck, L. Caffy, I. Delqué-Količ, E. Moreau C. Lebon, M. 2017. Comparison of two bone preparation methods for radiocarbon dating: modifies Longin and ninhydrin. Radiocarbon. 53 (6): 18351844.

Fischer-Genz, B. Genz, H. Elias, N. and Doumet-Serhal, C. 2018. Report on the 2017 archaeological soundings at Qornet ed-Deir, Jabal Moussa Biosphere Reserve. Bulletin d'Archéologie et d'Architecture Libanaise. 17: 245-262.

Harfouche, R. Poupet, P. 2017. Les sepultures du Tell el-Kharayeb et alentour. Pp189201, In : Paysage et peuplement du Mont Liban. La vallée du Nahr Ibrahim et l'hinterland de Byblos. Bulletin d'Archéologie et d'Architecture Libanaise. Hors Serie XVII, Harfouche, R. Poupet, P. Baldi, J. S. Yazbeck, C. Abdallah, C. Herveux, L. Homsy-Gottwalles, G. Abboud, M. and Zaven, T. Ministère de la Culture Direction Générale de l'Antiquité, 314 pp, Beirut.

Hedges, R. E. M. Van Klinken, G. J. 1992. A review of current approaches in the treatment of bone for radiocarbon dating by AMS. Radiocarbon. 34 (3): 269291.

Hedges, R. E. M. 2002. Bone diagenesis: An overview of processes. Archaeometry. 44(3): 319-328.

Kendall, C. Høier Eriksen, A. M. Kontopoulos, I. Collins, M. J. Turner-Walker, G. 2018. Diagenesis of archaeological bone and tooth. Palaeogeography, Palaeoclimatology, Palaeoecology. 491: 21-37.

Lebon, M. Reiche, I. Gallet, X. Bellot-Gurlet, L. Zazzo, A. 2016. Rapid quantification of bone collagen content by ATR-FTIR spectroscopy. Radiocarbon. 58 (1): 131145.

Pestle, W. J. Brennan, V. Sierra, R. L. Smith, E. K. Vesper, B. J. Cordell, G. A. Colvad M. D. 2015. Hand-held Raman spectroscopy as a pre-screening tool for archeological bone. Journal of archeological sciences. 58: 113-120.

Saliège, J.F. Zazzo, A. Hatté, C. Gauthier, C. 2013. Radiocarbon dating in Petra: limitations and potential in semi-arid environments. Pp 79-91, In: Men on the Rock, the formation of Nabataean Petra. M. Mouton \& S. G. Schmid. 361 pp. Berlin.

Scirè Calibrisotto, C. Fedi, M. E., Caforio, L. Bombardieri, L. Mando, P. A. 2013. Collagen quality indicators for radiocarbon dating of bones: new data on Bronze Age Cyprus. Radiocarbon 55(2-3): 472-480.

Smith, C. I. Nielsen-Marsh, C. M. Jans, M. M. E. Arthur, P. Nord, A. G. Collins, M. J. 2002. The strange case of Apigliano: 'Early Fossilization' of Medieval bone in Southern Italy. Archaeometry. 44(3): 405-415. 
Smith, C. I. Nielson-Marsh, C. M. Jans, M. M. E. Collins, M. J. 2007. Bone diagenesis in the European Holocene I: Patterns and mechanisms. Journal of Archeological Science. 34: 1485-493.

Storm, P. Wood, R. Stringer, C. Bartsiokas, A. De Vos, J. Aubert, M. Kinsley, L. Grün, R. 2013. U-series and radiocarbon analyses of human and faunal remains from Wajak, Indonesia. Journal of Human Evolution. 64: 356-365.

Taylor, R. E. Bar-Yosef, O. 2014. Radiocarbon Dating: An Archaeological Perspective, second edition, 404pp, New York.

Taylor, R. E. 2018. Radiocarbon Dating in Archaeology. Encyclopedia of Global Archaeology. https://doi.org/10.1007/978-3-319-51726-1

Tisnérat-Laborde, N. Valladas, H. Kaltnecker, E. Arnold, M. 2003. AMS radiocarbon dating of bones at LSEC. Radiocarbon. 45(3): 409-419.

Van Klinken, G. J. 1999. Bone Collagen Quality Indicators for Palaeodietary and Radiocarbon Measurements. Journal of Archaeological Science. 26: 687-695.

Weiner, S and Bar-Yosef. 1990. States of Preservation of Bones from Prehistoric Sites in the Near East: A Survey. Journal of Archaeological Science. 17: 187-196.

Wood, R. E. Barroso-Ruíz, C. Caparrós, M. Jordá Pardo, J. F. Santos, B. G. Higham, T. F. G. 2013. Radiocarbon dating casts doubt on the late chronology of the Middle to Upper Palaeolithic transition in southern Iberia. Proceedings of the National Academy of Sciences of the United States of America. 110: 2781-2786.

Wood, R. 2015. From revolution to convention: The past, present and future of radiocarbon dating. Journal of Archeological Science. 56: 61-72.

Zazzo, A. Saliège, J. F., Person, A. Boucher, H. 2009. Radiocarbon dating of calcinated bones: Where does the carbon come from? Radiocarbon. 51(2): 601-611. 